Analysis

\title{
Positive outcomes between crop diversity and agricultural employment worldwide
}

\author{
Lucas A. Garibaldi*, Néstor Pérez-Méndez \\ Instituto de Investigaciones en Recursos Naturales, Agroecología y Desarrollo Rural (IRNAD), Sede Andina, Universidad Nacional de Río Negro (UNRN) and Consejo \\ Nacional de Investigaciones Científicas y Técnicas (CONICET), Mitre 630, CP 8400 San Carlos de Bariloche, Río Negro, Argentina
}

\section{A R T I C L E I N F O}

\section{Keywords:}

Agriculture

Employment

Diversity

Human wellbeing

Rural development

\begin{abstract}
A B S T R A C T
Understanding the links between biodiversity-friendly landscapes and human wellbeing is key for supporting policy agendas from local to global scales. United Nations Sustainable Development Goals propose full employment (SDG 8) and crop diversity (SDG 2), but it is unclear if there are trade-offs between these goals across rural landscapes worldwide. We tested this idea with agricultural and socio-economic data for 44 countries from all continents during a 15-year period (1999-2013). We show that countries where crop diversity increased also supported more agricultural jobs. Such effects were independent of differences among countries in the size of the agricultural sector or fertilizer use (a proxy for the investment in external inputs and technology incorporation). Greater crop diversity was also compatible with improved crop yields and was not confounded with changes in socio-economic development or economic growth. In general, we found no evidence that the jobs lost in the rural areas were incorporated into other sectors of the economy. Unemployment is a major concern affecting livelihoods all over the world; policies to enhance crop diversity and prevent the loss of associated agricultural jobs are urgently needed.
\end{abstract}

\section{Introduction}

The consequences of biodiversity loss for human wellbeing are a major concern on the global policy agenda. During the past decades, a myriad of approaches have been developed to value nature's contribution to people (Pascual et al., 2017). Intergovernmental initiatives have emerged (Díaz et al., 2015) to support policy makers with scientific evidence showing that biodiversity loss has widespread ecological, social, economic, and cultural impacts from local to global scales (Díaz et al., 2018). However, although reducing unemployment is one of the major political challenges for nations all over the world (Kühn et al., 2018; Rifkin, 1995), links between employment and diversity remain to be explored. This is particularly relevant in the context of the United Nations Sustainable Development Goals to provide full employment (SDG 8) and crop diversity (SDG 2) (United Nations, 2015).

Agriculture occupies almost half of the terrestrial ice-free surface and employs around one-third of the human workforce (Erb et al., 2016; Kühn et al., 2018). Crops have different resource requirements, are associated with disparate agricultural practices, and are cultivated at different times throughout the year. We thus hypothesize that higher crop diversity will require a more diverse set of inputs, logistics, machinery, skills, and services throughout the year ("employment niches"). Moreover, crops can have different processing and commercialization chains. Landscapes with higher crop diversity also provide more resources for other rural economic activities such as beekeeping or tourism (Garibaldi et al., 2017b). Therefore, higher crop diversity should provide a greater number of jobs in rural areas.

We tested this expectation with agricultural and socio-economic data for 44 countries from all continents during a 15-year period (1999-2013, with 2013 being the last year with data available). We used linear models to understand how annual growth in the number of agricultural employees (and the proportion of total employees that work in agriculture) varied as a function of the annual growth in crop evenness across countries. The number of crop species, i.e. crop richness, changed little during the study period. Therefore, greater evenness in the distribution of area among crops (Fig. 1) implies higher crop diversity. Cultivated area and fertilizer use were included in the models to control for other important predictors.

\section{Methods}

To assess the importance of crop diversity in promoting agricultural employment we compiled a data set at the country scale from the Food and Agriculture Organization (FAO) of the United Nations (FAO, 2017),

\footnotetext{
* Corresponding author.

E-mail address: lgaribaldi@unrn.edu.ar (L.A. Garibaldi).
} 

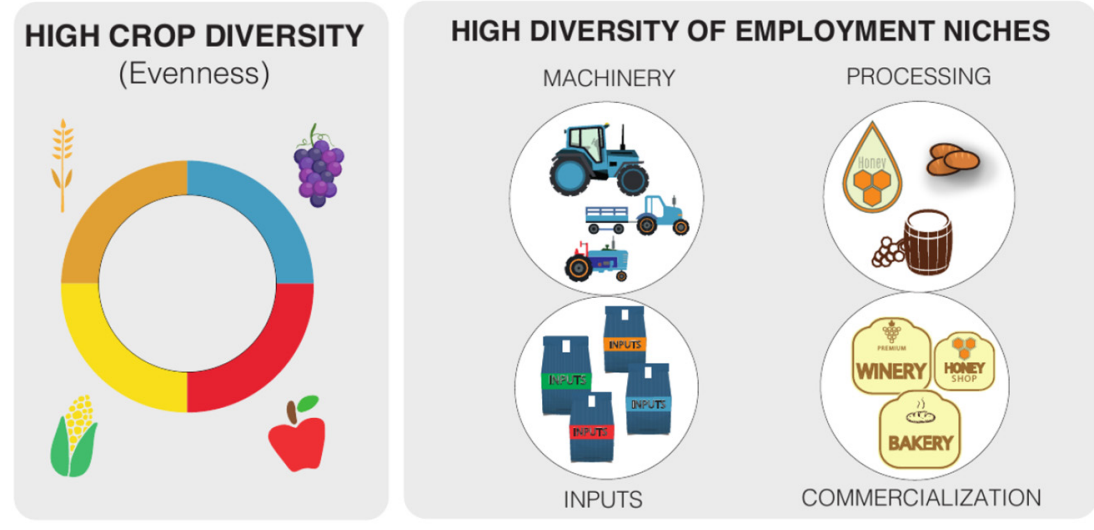

\section{INCREASED EMPLOYMENT}

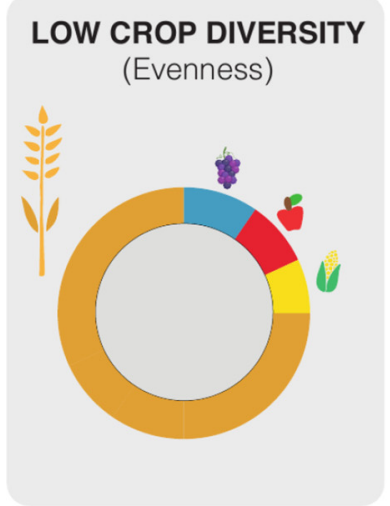

\section{LOW DIVERSITY OF EMPLOYMENT NICHES}

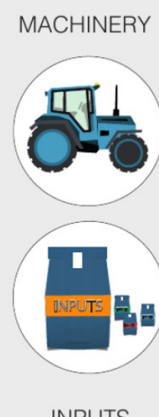

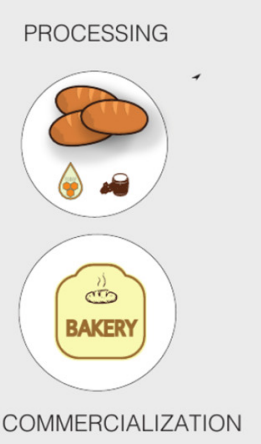

DECREASED EMPLOYMENT

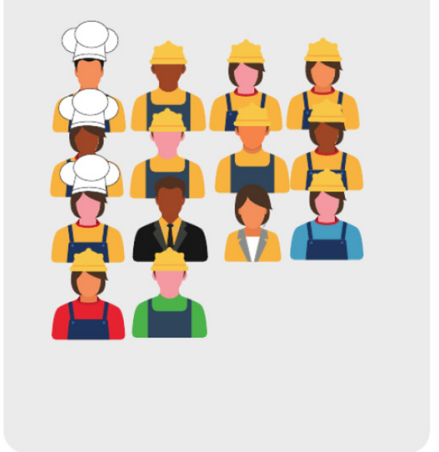

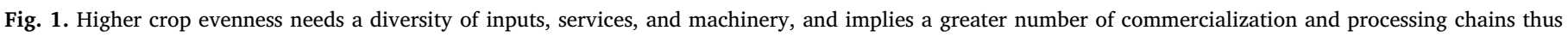

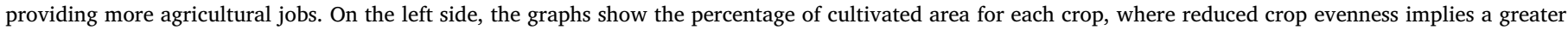
dominance of one or a few crops.

the United Nations Development Programme (UNDP, 2016) and the World Bank Group (World Bank Group, 2017). We searched for data from all countries in the world, but in order to maximize data quality we only considered countries with complete data series for the indicators of interest (see below) or presenting at most one missing value. In these cases, the average value between the previous and posterior year was calculated. Attending to this criterion we subset a time window of 15 years (1999-2013) for 44 countries from all continents and contrasting socio-economic conditions (Fig. 2).

We compiled annual data for two proxies of agricultural employment for each country. First, employees in agriculture was defined as the number of persons of working age (15-65) who conducted an agricultural activity according to the International Standard Industrial Classification of All Economic Activities (ISIC) (United Nations, 2008). This category includes growing of crops, raising and breeding of animals, harvesting of timber and other plants, animals or animal products from a farm or their natural habitats. However, it excludes all subsequent activities of manufacturing or commercialization of the agricultural products (e.g. manufacturing of food products and beverages, tobacco manufacturing). Second, the proportion of agriculture employment was defined as the proportion of agriculture employment in total employment (FAO, 2017). Employment data is provided to the FAO by member countries, which obtain estimates through different sources. To avoid biases in the estimates of the employment we only considered data provided by the same source within each country.

To estimate crop diversity, we obtained annual data on the harvested area (hectares) for 163 crops or groups of crops (e.g. Canella crop includes the two species Cinnamomum zeylanicum and C. cassia) for each country. A few crop species (e.g. onions dry and onions shallots; or green beans and dry beans) are considered by FAO as different crops, as they represent different varieties or the method of cultivation is substantially different (FAO, 2017). Crop diversity can be split into two main components: richness (i.e. the number of crops) and evenness (Smith and Wilson, 1996). However, at the country level, crop richness varied little during the study period (this is expected because most countries already cultivate at least a few hectares of most crops). By using the harvested area as a proxy of the abundance of each crop, we calculated the Pielou's $J$ as a measure of evenness. It ranges between 0 and 1, with larger values indicating more equal distribution of abundances across crops (Pielou, 1975). Given the lack of variation in crop richness, common diversity indexes (such as Shannon and Simpson) were highly and positively correlated with Pielou's $J$ (data not shown).

We additionally compiled information on cultivated area and fertilizer use, which in close relationship with crop evenness, are expected to shape the patterns of agricultural employment. We obtained data from the FAO on the sum of harvested areas of all crops (total harvested area; hectares) that reflects the size of the agricultural sector, and the use of synthetic nitrogen fertilizer (fertilizer use; $\mathrm{kg}$ of nutrients) that reflects the investment of countries in external inputs and technology incorporation (FAO, 2017). Lack of data for the complete temporal series (1999-2013) prevented the use of additional proxies of technology incorporation such as investment in machinery (FAO, 2017). We expected that annual growth in agricultural employees will increase with cultivated area but decrease with fertilizer use (Chand and Srivastava, 2014; Dorin, 2017).

Variation in crop evenness across countries could be correlated with changes in important socio-economic and agricultural variables. Therefore, we obtained the Human Development Index (HDI) from the United Nations Development Programme (UNDP, 2016) and the Gross Domestic Product (GDP) from the World Bank Group (World Bank Group, 2017). Additionally, the number of non-agricultural employees and crop yield (hg hectare ${ }^{-1}$ ) were obtained with the same method 


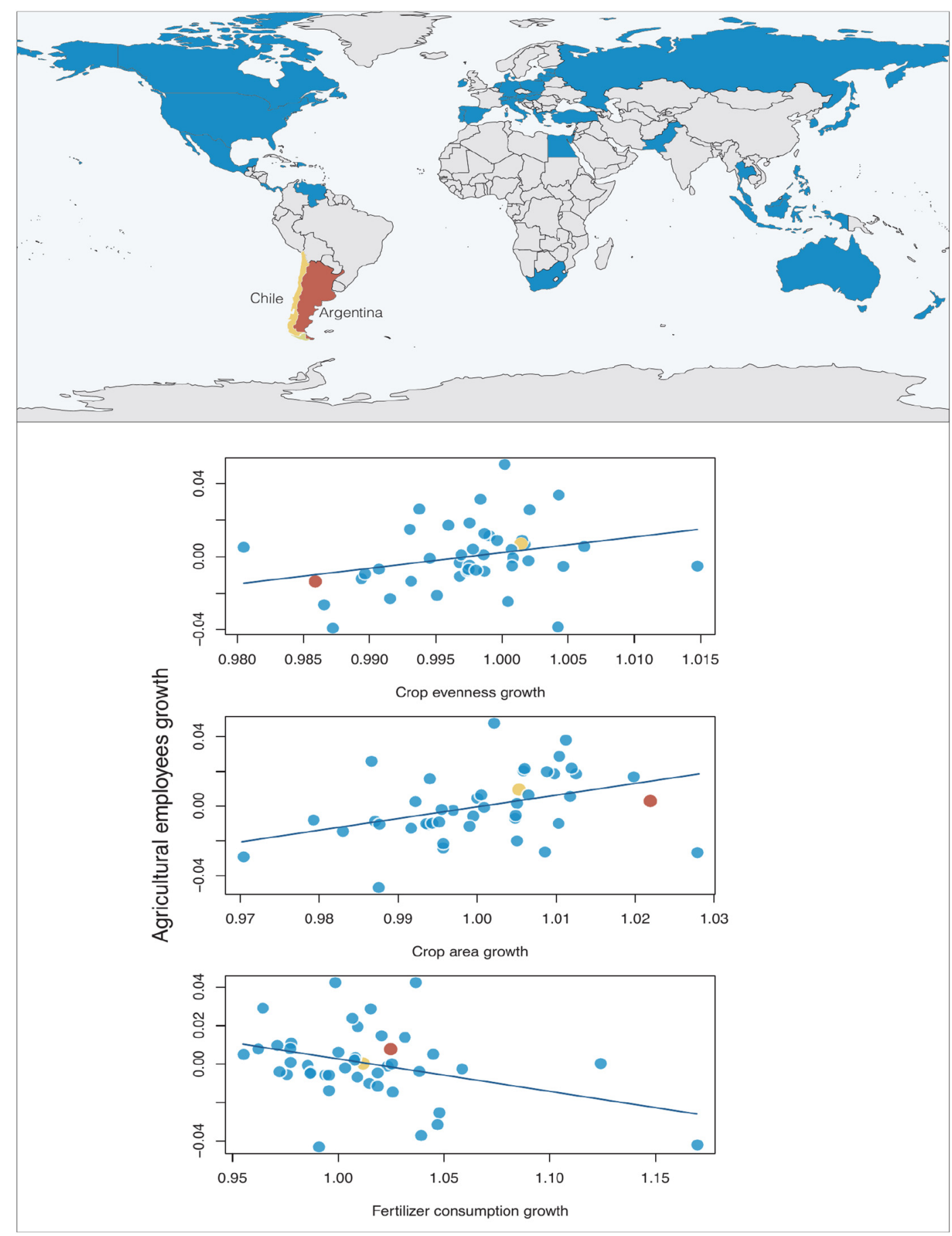

Fig. 2. Worldwide, annual growth in the number of agricultural employees increase with crop evenness and crop area but decrease with fertilizer consumption. The map shows the 44 countries analyzed. In the case of agricultural employees, the graphs show the residuals of a model containing all the predictor variables except the one that is being presented in the x-axis. Argentina and Chile, two examples discussed in more detail in the text, are depicted in different colors.

used for agricultural employees and harvested area, respectively (see descriptions above).

For all the variables, we estimated the annual growth rate according to $\Delta X_{\mathrm{t}}=\left(X_{\mathrm{t}} / X_{\mathrm{t}-1}\right)$, were $\Delta X_{\mathrm{t}}$ is the growth rate of a given variable in year $t$ relative to the previous year ( $t-1)$, giving 14 values for the 15 year period. The geometric mean was estimated for the study period for each variable, which is more appropriate than the arithmetic mean for describing such proportional growth (McAlister, 1879).

A linear model was estimated for the annual growth in the number of agricultural employees as a response variable and evenness, total harvested area, and fertilizer use as predictors. Statistical inference was performed through ANOVA (Table 1). The same analyses were done for annual growth in the proportion of agricultural employees as a response variable. Models were estimated with the gls function from the nlme package (Pinheiro et al., 2014) in the R Software (R Core Team, 2016). Model and ANOVA assumptions (normal distribution, homogeneous variances, linearity, and independence) were met according to residual analyses (e.g. quantile-quantile plots, graphs of residual vs. fitted values, graphs of residuals vs. leverage, graphs of observed vs. fitted values), which also indicated that non-linear functions between response and predictor variables were unnecessary. Variance inflation factors (VIFs) were lower than 1.7 in all cases. We repeated all the analyses 
Table 1

Linear models of the annual growth in the number of agricultural employees (and the proportion of total employees that work in agriculture) as a function of the annual growth in fertilizer use, crop area, and crop evenness. $F$ scores from marginal (type 3 ) ANOVAs. $\beta$ : partial regression coefficients and standard errors (in parenthesis). ${ }^{\dagger} P<0.10,{ }^{*} P<0.05,{ }^{*} * P<0.01$.

\begin{tabular}{llllll}
\hline & \multicolumn{2}{l}{ Number employees } & & \multicolumn{2}{l}{ Proportion employees } \\
\cline { 2 - 3 } \cline { 5 - 6 } & $F$ & $\beta$ & & $F$ & $\beta$ \\
\hline Fertilizer use & $8.3^{* *}$ & $-0.22(0.076)$ & & $6.4^{*}$ & $-0.16(0.062)$ \\
Crop area & $10.9^{* *}$ & $1.0(0.31)$ & & $4.5^{*}$ & $0.53(0.25)$ \\
Crop evenness & $6.7^{*}$ & $1.4(0.54)$ & & $3.2^{\dagger}$ & $0.78(0.44)$ \\
\hline
\end{tabular}

using $\log _{10}$ on response and all predictor variables to reduce the possible influence of extreme values, and these analyses yielded the same results (compare Table 1 with Appendix Table 1). The inclusion of interactions among predictor variables did not improve model fit and increased VIFs considerably (no interaction was found to be significant).

\section{Results and discussion}

Worldwide, while the demand for agricultural products has been increasing at high rates (Godfray et al., 2010), the number of agricultural employees has been decreasing for $75 \%$ of the countries examined (i.e., annual growth rates $<1$, Fig. 2). Similarly, during 1999-2013, crop evenness has decreased for $66 \%$ of the countries. Across countries, annual growth in the number of employees varied at a greater rate with evenness than with cultivated area or fertilizer consumption (compare magnitudes of the partial regression coefficients in Table 1). Moreover, annual growth in the number of employees increased with annual growth in crop evenness at a rate that was more than proportional, as the partial regression coefficient $(\beta)$ was $>1$ $(\beta=1.4$, Table 1$)$. As expected, cultivated area was positively associated with the growth in agricultural employees $(\beta=1)$, whereas fertilizer consumption showed a negative relation ( $\beta=-0.22$, Fig. 2). The proportion of agricultural employees showed similar directional trends (Table 1). Therefore, countries with greater growth in crop evenness have more agricultural jobs and these effects are not confounded with the size of the agricultural sector or technology incorporation.

The effects of evenness are not confounded with differences in development or economic growth among countries either. We found no association between the annual growth in crop evenness and the annual growth in human development index (Spearman's $r=0.075, P=0.63$ ) or gross domestic product (Spearman's $r=0.16, P=0.31$ ). Given that our sampling included low- to high-income countries (Fig. 2), different policies to promote crop diversity could be designed successfully in countries with contrasting socio-economical contexts. Overall, our results agree with a recent study that shows the global importance of diverse landscapes for producing micronutrients and protein (Herrero et al., 2017), and add that such landscapes could also provide more agricultural jobs. In this context, the reduction in crop evenness found here for many countries can have consequences on multiple dimensions, including the loss of local and traditional crops, contributing to the global homogenization of diets across countries (Khoury et al., 2014).

It could be expected that countries losing agricultural employees at a higher rate incorporate such labor force into industrial or service sectors (structural transformation; (Bryden and Bollman, 2000; Dorin, 2017; Rifkin, 1995). Such compensation could be especially important if overall unemployment is low (Kühn et al., 2018; Rifkin, 1995). However, annual growth in agricultural employees correlated positively with growth in non-agricultural employees across countries (Spearman's $r=0.31, P=0.040$ ), possibly reflecting concomitant economic growth across sectors. Interestingly, the fact that the proportion and absolute numbers of agricultural employees showed similar trends (Table 1), indicates that agricultural employees increased at a faster rate than non-agricultural employees with crop evenness, providing further support for a direct link between agricultural employment and crop evenness (Fig. 1). Therefore, our results suggest that policies could be designed to enhance crop evenness and agricultural labor without compromising (or even promoting) other economic sectors. During the past decades, when new technologies have replaced workers in a given sector, other sectors have grown to absorb workers (Kühn et al., 2018; Rifkin, 1995). However, nowadays, all the traditional economic sectors (agriculture, manufacturing, and service) are experiencing technological changes that generate unemployment (Kühn et al., 2018; Rifkin, 1995). The knowledge sector is growing, but employs only a relatively small amount of people, and thus it is not expected to absorb the displaced laborers (Kühn et al., 2018; Rifkin, 1995).

Global decreases in crop evenness are associated with conventional intensification, the main process driving agricultural production during the past decades (Garibaldi et al., 2017a). Conventional intensification consists of increasing crop field size, creating more homogeneous landscapes (i.e. less evenness), and increasing use of agrochemicals, including fertilizers (Garibaldi et al., 2017a). Therefore, it could be expected that countries with higher growth rates in crop evenness show lower growth in fertilizer use and potentially lower crop yields. However, we found no association between growth in evenness and fertilizer use (Spearman's $r=-0.19, P=0.22$ ) or growth in agricultural yield (Spearman's $r=0.22, P=0.14$ ), and the effects of evenness on employment were independent from those of fertilizer use (Fig. 2, Table 1). Thus, the enhancement of crop evenness in agricultural landscapes is compatible with technology incorporation and does not compromise crop yields.

To exemplify these global trends, let's consider Argentina and Chile, two neighboring countries in which primary production is important for their national economies (Kerrigan Richard, 2016; Neffa, 2018). Argentina was one of the countries with the highest losses of crop evenness, while Chile showed the opposite pattern with a net increase in crop evenness (Fig. 3; growth rate: 0.986 vs. 1.002 , respectively). Accordingly, Argentina had a greater loss in agricultural jobs than Chile (growth rate: 0.979 vs. 0.995 , respectively), despite a greater increase in agricultural area (growth rate: 1.022 vs. 1.005 , respectively). In Argentina, the loss of evenness was associated with a rapid soybean expansion (Aizen et al., 2009) (Fig. 3), which represented the most important export and cash source, and corresponded with a large rural to urban migration (Neffa, 2018). Rural migrants did not find proper jobs in Argentinean cities, increasing the size and number of poor and informal settlements ("villas miseria") (Neffa, 2018). In contrast, in Chile, several crops expanded (Fig. 3), especially berries, nuts, grapes, olives, and maize, while other crops that covered large areas of land in the past decreased noticeably (e.g. wheat, tomatoes, and sugar beet) (FAO, 2017). The increasing crops are commonly cultivated in smaller areas than Argentinean soybeans, thus creating more heterogeneous landscapes (Kerrigan Richard, 2016). Chilean policies included subsidies to small agricultural enterprises, and productivity per rural employee and women's share of agricultural labor increased (Kerrigan Richard, 2016). Additionally, the relative remuneration for agricultural labor with regard to other sectors of the economy increased (although this remuneration is still low in comparison to other sectors), improving the livelihoods of agricultural employees (Kerrigan Richard, 2016). The patterns observed across time in Argentina and Chile, are also confirmed when absolute values at the beginning of the studied period (1999) are compared. Argentina had a much lower initial evenness than Chile (Pielou's J: 0.49 vs 0.69, respectively), associated with 268 times fewer agricultural employees per 10,000 ha in comparison to Chile (25 vs. 6700 , respectively). In summary, a greater diversity of crops due to smaller field sizes and higher crop richness in Chile was associated with 

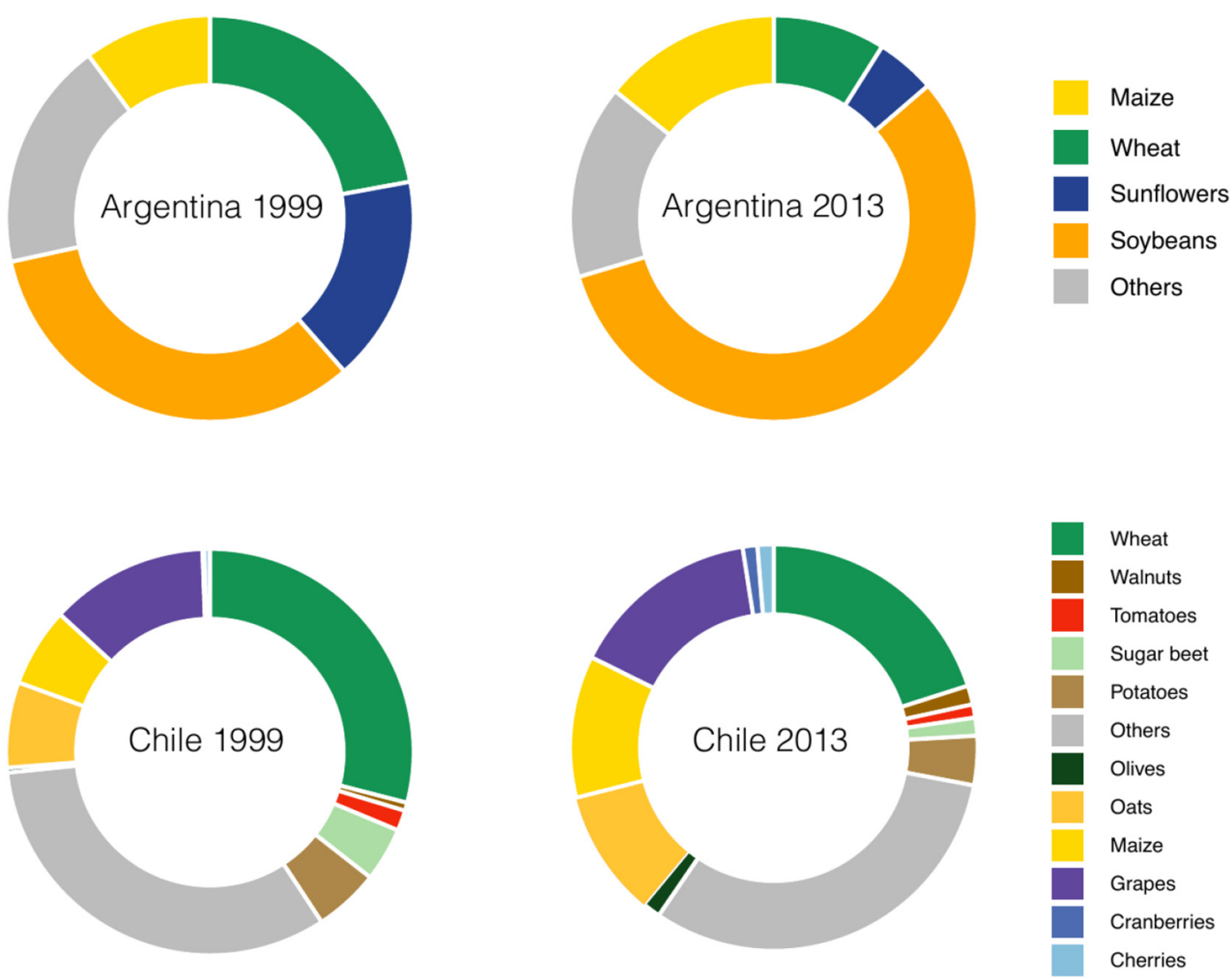

Fig. 3. Argentina suffered an important reduction in crop evenness during the study period, while evenness in Chile slightly increased. Each graph shows the percentage of cultivated area for each crop.

smaller loss of agricultural jobs and improved labor conditions (Kerrigan Richard, 2016). We would like to emphasize that our results refer to the national scale, but it is unclear whether these trends hold for smaller landscapes. This is an important knowledge gap that should be considered in the design of future studies.

Unemployment is a serious problem worldwide (Kühn et al., 2018; Rifkin, 1995). Most research has focused on the consequences of biodiversity loss on ecosystem functions and services (Cardinale et al., 2012; Díaz et al., 2006; Isbell et al., 2017), but the impacts on the multiple dimensions of human wellbeing remain unclear. Such knowledge is important to support relevant policies from local to global scales, including the United Nations Sustainable Development Goals to provide full employment (SDG 8), while enhancing crop diversity (SDG 2) (United Nations, 2015). Here we show that both aspects are linked at the country level, with the potential to create rural landscapes that maintain high crop diversity and provide more jobs. Such trends could be compatible with improved technology, crop yields, wages, and labor conditions (Kerrigan Richard, 2016). While our analyses focused on direct agricultural jobs (United Nations, 2008), it is likely that the effects of diversity are greater if indirect jobs associated to agricultural activity and post-production processing (e.g. manufacture of food products and beverages) are also included. Policies to revert the ongoing worldwide loss of crop evenness and associated agricultural jobs are urgently needed.

\section{Acknowledgments}

We are very grateful to the editor and two anonymous referees for their constructive insights that helped us to significantly improve our contribution. We are indebted to Sebastián Aguiar, Marcelo Aizen, Francisco Aristimuño, Kate Brauman, Tom Breeze, José Miguel Campos, Saul Cunningham, Barbara Gemmill-Herren, Juan Pedro GonzálezVaro, Pablo Hünicken, Sergio Lambertucci, Unai Pascual, Walter Pengue, Noa Simon, Matthew Smith, Pablo Tittonell, Lucas Vitantonio, and Federico Zuberman for invaluable comments on earlier version. We appreciate funding from Consejo Nacional de Investigaciones Científicas y Técnicas and Universidad Nacional de Río Negro (PI 40-B399, PI 40-B-567).

\section{Appendix A}

Appendix Table 1

Linear models of $\log _{10}$ annual growth in the number of agricultural employees (and the proportion of total employees that work in agriculture) as a function of $\log _{10}$ annual growth in fertilizer use, crop area, and crop evenness. $F$ scores from marginal (type 3 ) ANOVAs. $\beta$ : partial regression coefficients and standard errors (in parenthesis). ${ }^{\dagger} P<0.10,{ }^{*} P<0.05,{ }^{* *} P<0.01$.

\begin{tabular}{|c|c|c|c|c|}
\hline & \multicolumn{2}{|c|}{$\log _{10}$ number employees } & \multicolumn{2}{|c|}{$\log _{10}$ proportion employees } \\
\hline & $F$ & $\beta$ & $F$ & $\beta$ \\
\hline $\log _{10}$ fertilizer use & $8.4^{* *}$ & $-0.24(0.081)$ & $6.5^{*}$ & $-0.17(0.067)$ \\
\hline $\log _{10}$ crop area & $11.0^{* *}$ & $1.04(0.31)$ & $4.6^{*}$ & $0.55(0.26)$ \\
\hline $\log _{10}$ crop evenness & $6.8^{*}$ & $1.4(0.55)$ & $3.2^{\dagger}$ & $0.80(0.45)$ \\
\hline
\end{tabular}




\section{References}

Aizen, M.A., Garibaldi, L.A., Dondo, M., 2009. Soybean expansion and agriculture diversity in Argentina. Ecol. Austral 19, 45-54.

Bryden, J., Bollman, R., 2000. Rural employment in industrialised countries. Agric. Econ. 22, 185-197. https://doi.org/10.1016/S0169-5150(99)00053-5.

Cardinale, B.J., Duffy, J.E., Gonzalez, A., Hooper, D.U., Perrings, C., Venail, P., Narwani, A., Mace, G.M., Tilman, D., Wardle, D.A., Kinzig, A.P., Daily, G.C., Loreau, M., Grace, J.B., Larigauderie, A., Srivastava, D.S., Naeem, S., 2012. Biodiversity loss and its impact on humanity. Nature 486, 59-67. https://doi.org/10.1038/nature11148.

Chand, R., Srivastava, S.K., 2014. Changes in the rural labour market and their implications for agriculture. Econ. Polit. Wkly. XLIX, 47-54.

Díaz, S., Fargione, J., Chapin, F.S., Tilman, D., 2006. Biodiversity loss threatens human well-being. PLoS Biol. 4, e277. https://doi.org/10.1371/journal.pbio.0040277.

Díaz, S., Demissew, S., Joly, C., Lonsdale, W.M., Larigauderie, A., 2015. A Rosetta stone for nature's benefits to people. PLoS Biol. 13, e1002040. https://doi.org/10.1371/ journal.pbio.1002040.

Díaz, S., Pascual, U., Stenseke, M., Martín-López, B., Watson, R.T., Molnár, Z., Polasky, S., 2018. Assessing nature's contributions to people. Science 359, 270-272. https://doi. org/10.1126/science.aap8826.

Dorin, B., 2017. India and Africa in the global agricultural system (1961-2050). Towards a new sociotechnical regime? Econ. Polit. Wkly. LII, 5-13.

Erb, K.-H., Lauk, C., Kastner, T., Mayer, A., Theurl, M.C., Haberl, H., 2016. Exploring the biophysical option space for feeding the world without deforestation. Nat. Commun. 7, 11382. https://doi.org/10.1038/pj.2016.37.

FAO, 2017. FAOSTAT [WWW Document]. Food Agric. Organ. United Nations. URL http: //faostat. fao.org/site/377/default. aspx\#ancor.

Garibaldi, L.A., Gemmill-Herren, B., D'Annolfo, R., Graeub, B.E., Cunningham, S.A., Breeze, T.D., 2017a. Farming approaches for greater biodiversity, livelihoods, and food security. Trends Ecol. Evol. 32, 68-80. https://doi.org/10.1016/j.tree.2016.10. 001.

Garibaldi, L.A., Requier, F., Rollin, O., Andersson, G.K.S., 2017b. Towards an integrated species and habitat management of crop pollination. Curr. Opin. Insect Sci. 21, 1-10. https://doi.org/10.1016/j.cois.2017.05.016.

Godfray, H.C.J., Beddington, J.R., Crute, I.R., Haddad, L., Lawrence, D., Muir, J.F., Pretty, J., Robinson, S., Thomas, S.M., Toulmin, C., 2010. Food security: the challenge of feeding 9 billion people. Science 327, 812-818. https://doi.org/10.1126/science. 1185383

Herrero, M., Thornton, P.K., Power, B., Bogard, J.R., Remans, R., Fritz, S., Gerber, J.S., Nelson, G., See, L., Waha, K., Watson, R.A., West, P.C., Samberg, L.H., van de Steeg, J., Stephenson, E., van Wijk, M., Havlík, P., 2017. Farming and the geography of nutrient production for human use: a transdisciplinary analysis. Lancet Planet. Heal.
1, e33-e42. https://doi.org/10.1016/S2542-5196(17)30007-4.

Isbell, F., Gonzalez, A., Loreau, M., Cowles, J., Díaz, S., Hector, A., Mac, E.G.M., Wardle, D.A., O'Connor, M.I., Duffy, J.E., Turnbull, L.A., Thompson, P.L., Larigauderie, A., 2017. Linking the influence and dependence of people on biodiversity across scales. Nature 546, 65-72. https://doi.org/10.1038/nature22899.

Kerrigan Richard, G., 2016. Tendencias del empleo y la productividad laboral en el sector agropecuario de Chile. Naciones Unidas, Santiago de Chile.

Khoury, C.K., Bjorkman, A.D., Dempewolf, H., Ramirez-Villegas, J., Guarino, L., Jarvis, A., Rieseberg, L.H., Struik, P.C., 2014. Increasing homogeneity in global food supplies and the implications for food security. Proc. Natl. Acad. Sci. U. S. A. 111, 4001-4006. https://doi.org/10.1073/pnas.1313490111.

Kühn, S., Milasi, S., Yoon, S., 2018. World Employment and Social Outlook: Trends 2018. Ilo. International Labour Organization, Geneva.

McAlister, D., 1879. The law of the geometric mean. Proc. R. Soc. Lond. 29, 367-376.

Neffa, J.C., 2018. Modes of development, work and employment in Argentina (20022017). Rev. Estado y Políticas Públicas 9, 93-119.

Pascual, U., Balvanera, P., Díaz, S., Pataki, G., Roth, E., Stenseke, M., Watson, R., Dessane, E., Breslow, S., Islar, M., Kelemen, E., Keune, H., Maris, V., Pengue, W., Quaas, M. Subramanian, S., Wittmer, H., Mohamed, A., Al-Hafedh, Y., Asah, S., Berry, P., Bilgin, E., Bullock, C., Cáceres, D., Golden, C., Gómez-Baggethun, E., González-Jiménez, D., Houdet, J., Kumar, R., May, P., Mead, A., O'Farrell, P., Pacheco-Balanza, D., Pandit, R., Pichis-Madruga, R., Popa, F., Preston, S., Saarikoski, H., Strassburg, B., Verma, M., Yagi, N., Ahn, S., Amankwah, E., Daly-Hassen, H., Figueroa, E., Ma, K., van den Belt, M., Wickson, F., 2017. Valuing nature's contributions to people: the IPBES approach. Curr. Opin. Environ. Sustain. 26, 6-17. https://doi.org/10.1016/j.cosust.2016.12. 006.

Pielou, E.C., 1975. Ecological Diversity. Wiley, New York, USA.

Pinheiro, J., Bates, D., Deb Roy, S., Sarkar, D., Team, R.D.C., 2014. Nlme: Linear and Nonlinear Mixed Effects Models. R Package Version 3.1-117.

R Core Team, 2016. R: A Language and Environment for Statistical Computing. R Foundation for Statistical Computing, Vienna, Austria.

Rifkin, J., 1995. The End of Work: The Decline of the Global Labor Force and the Dawn of the Post-Market Era. G. P. Putnam's Sons, New York, USA.

Smith, B., Wilson, J.B., 1996. A consumer's guide to evenness indices. Oikos 76, 70-82. UNDP, 2016. Human Development Report 2016, United Nations Development Programme. https://doi.org/eISBN: 978-92-1-060036-1.

United Nations, 2008. International Standard Industrial Classification of all Economic Activities (ISIC), Revision 4. United Nations, New York, USA.

United Nations, 2015. Transforming our World: The 2030 Agenda for Sustainable Development [WWW Document]. A/RES/70/1. https://doi.org/10.1007/s13398 014-0173-7.2.

World Bank Group, 2017. World Bank Group [WWW Document]. 